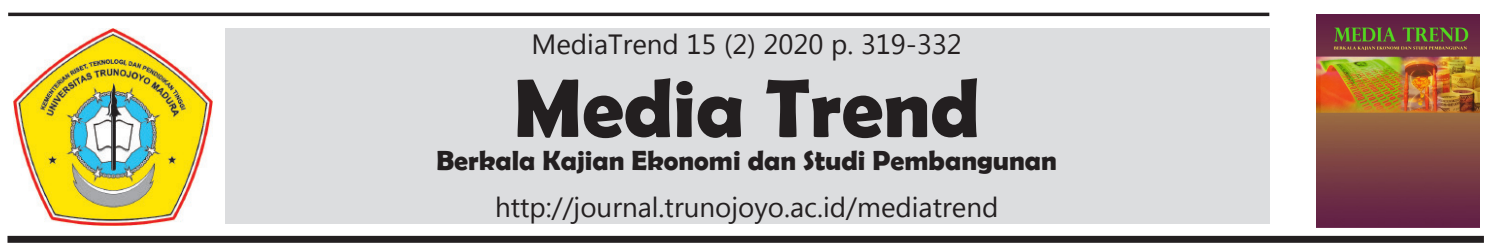

\title{
Peran Perempuan dalam Meningkatkan Ketahanan Pangan Rumah Tangga di Provinsi Nusa Tenggara Barat
}

\author{
Triana Pujilestari ${ }^{*}$, Tri Haryanto ${ }^{2}$ \\ ${ }^{1,2}$ Universitas Airlangga
}

\section{Informasi Artikel \\ Sejarah artikel: \\ Diterima Juni 2020 \\ Disetujui September 2020 \\ Dipublikasikan Oktober 2020}

\begin{abstract}
A BS TRACT
Food security at the national or regional level does not ensure food security at the household level. The study aim to analyze the influence of economic, demographic and social characteristics including the level of mother's education, mother's age, mother's occupation, access to the internet, household size, residential area, and household expenditure on the food security household level at NTB Province. Based on the data of The National Socioeconomic Survey (SUSENAS) March 2018 from Statistics Indonesia (BPS), this study is conducted by using multinomial logistic regression method to archieve the objective. The results show that the level of mother's education, mother's age, access to the internet, household size and household expenditure have significant effect to the food security household level at NTB province.
\end{abstract}

Keywords: Food security, Susenas, Multinomial Logistic Regression

\begin{abstract}
A BS T R A K
Ketahanan pangan di tingkat nasional atau daerah tidak menjamin ketahanan pangan di tingkat rumah tangga. Penelitian ini bertujuan untuk menganalisis pengaruh karakteristik ekonomi, demografi, dan sosial yang meliputi tingkat pendidikan ibu, usia ibu, pekerjaan ibu, akses internet, ukuran rumah tangga, wilayah pemukiman, dan pengeluaran rumah tangga terhadap ketahanan pangan tingkat rumah tangga di NTB. Propinsi. Berdasarkan data Survei Sosial Ekonomi Nasional (SUSENAS) Maret 2018 dari Badan Pusat Statistik (BPS), penelitian ini dilakukan dengan menggunakan metode regresi logistik multinomial untuk mencapai tujuan tersebut. Hasil penelitian menunjukkan bahwa tingkat pendidikan ibu, umur ibu, akses internet, ukuran rumah tangga dan pengeluaran rumah tangga berpengaruh signifikan terhadap tingkat ketahanan pangan rumah tangga di provinsi NTB.
\end{abstract}

Kata Kunci: Ketahanan Pangan, SUSENAS, Regresi Multinominal logit Kode Klasifikasi JEL: Q18; D12

(C) 2020 MediaTrend

Penulis korespondensi:

E-mail: trianapuji12@gmail.com

DOI: http://dx.doi.org/10.21107/mediatrend.v15i2.7439

2460-7649 @ 2020 MediaTrend. All rights reserved. 


\section{PENDAHULUAN}

Ketahanan pangan merupakan salah satu pilar utama untuk mewujudkan ketahanan nasional. Ketahanan pangan bagi suatu negara menjadi hal yang sangat penting terutama bagi negara yang mempunyai penduduk yang sangat besar dan terus meningkat seperti Indonesia. Beberapa penilaian tingkat ketahanan pangan Indonesia pada tahun 2017, diantaranya adalah Global Food Security Index (GFSI) yang diukur dari ketersediaan pangan, keterjangkauan, keamanan dan kualitas pangan; Indonesia berada pada urutan ke69 dari 113 negara. Sementara itu, Global Hunger Index (GHI) dengan indeks sebesar 22 Indonesia menempati peringkat ke-72 dari 119 negara. GHI disusun oleh International Food Policy Research Institute (IFPRI) dengan menggunakan empat aspek yaitu undernourishment, balita wasting, balita stunting, dan angka kematian bayi. Indeks ketahanan pangan lainnya adalah Rice Bowl Index (RBI) yang menempatkan Indonesia pada peringkat 10 dari 15 negara di Asia Pasifik.

Pangan dan gizi sangat erat kaitannya dengan upaya peningkatan sumber daya manusia Noviani et al., (2020). Ketersediaan pangan yang cukup untuk seluruh penduduk di suatu wilayah belum bisa digunakan sebagai jaminan akan terhindarnya penduduk dari masalah pangan dan gizi, karena selain ketersediaan perlu diperhatikan juga aspek pola konsumsi atau keseimbangan kontribusi di antara jenis pangan yang dikonsumsi, sehingga memenuhi standar gizi tertentu (Kara \& Kithu, 2020). Kekurangan konsumsi gizi bagi seseorang dari standar minimum umumnya akan berpengaruh terhadap kondisi kesehatan, aktivitas dan produktivitas kerja dimana dalam jangka panjang hal tersebut akan berpengaruh terhadap kualitas SDM (Heryanah, 2016).

Provinsi Nusa Tenggara Barat (NTB) merupakan daerah surplus pangan, hal tersebut diindikasikan dengan keterse- diaan produksi padi yang surplus dan ketersediaan pangan tumbuhan dan hewani lainnya yang cenderung meningkat. Hasil Survei Sosial Ekonomi Nasional (Susenas) Maret 2018 menunjukkan bahwa rata-rata konsumsi kalori penduduk NTB adalah sebesar 2.316,43 kkal, sudah berada di atas standar kecukupan konsumsi gizi nasional. Kementerian Kesehatan menetapkan Provinsi NTB sebagai salahsatu daerah rawan gizi buruk, dan menempati peringkat ke-2 angka gizi buruk dari 34 provinsi di Indonesia. Temuan ini didukung dengan hasil Pemantauan Status Gizi (PSG) oleh Dinas Kesehatan NTB yaitu adanya kenaikan angka prevalensi kurang gizi, dari 22,6 persen pada tahun 2017 naik menjadi 29,5 persen pada tahun 2018.

Hasil Survei Riset Kesehatan Dasar juga menemukan kondisi yang serupa. Sekitar 38 persen balita NTB masih mengkonsumsi energi (karbohidrat dan lemak) di bawah kebutuhan standar minimum. Demikian pula dengan persentase penduduk usia produktif. Penduduk usia produktif yang mengkonsumsi kalori dibawah standart AKG mencapai 38 persen di bawah kebutuhan minimum protein yang direkomendasikan. Keadaan ini menunjukkan bahwa pemanfaatan pangan terutama dalam hal mengkonsumsi gizi kalori oleh rumah tangga di provinsi NTB masih belum maksimal, padahal diharapkan dengan kondisi wilayah yang surplus pangan, NTB juga bisa meningkatkan tingkat ketahanan pangan rumah tangga dan meningkatkan sumber daya manusia yang berkualitas.

Penelitian Purwaningsih et al., (2015) menganalisis pola pengeluaran pangan menurut tingkat ketahanan pangan rumah tangga di Jawa Tengah. Tingkat ketahanan pangan rumah tangga dikelompokkan menjadi empat, yaitu tahan, kurang, rentan dan rawan pangan. Data yang digunakan adalah data Susenas yang berupa data mentah. Hasil penelitian menunjukkan terdapat perbedaan yang cukup besar dalam proporsi penge- 
luaran pangan antara rumah tangga tahan dan kurang pangan dengan rumah tangga rentan dan rawan pangan. Pada setiap tingkat ketahanan pangan rumah tangga, pengeluaran rumah tangga untuk makanan-minuman jadi menunjukkan proporsi tertinggi dibanding dengan kelompok pangan lain. Semakin tidak tahan pangan suatu rumah tangga, semakin tinggi proporsi pengeluaran untuk tembakau. Pada setiap kelompok rumah tangga menurut tingkat ketahanan pangan, rumah tangga di wilayah perkotaan mempunyai proporsi pengeluaran beras lebih kecil dibanding dengan rumah tangga di wilayah pedesaan. Berdasar hasil tersebut disarankan bahwa prioritas penanganan masalah ketahanan pangan harus diberikan pada kelompok rumah tangga rentan dan rawan pangan.

Penelitian Mulyo et al., (2016) bertujuan untuk mengetahui ketahanan pangan rumah tangga tani menggunakan pendekatan AKE, mengetahui ketahanan pangan rumah tangga tani menggunakan pendekatan PPP, mengetahui keragaan ketahanan pangan, dan mengetahui keadaan kemandirian pangan rumah tangga tani daerah marginal di Kabupaten Bojonegoro. Penelitian dilaksanakan di Kabupaten Bojonegoro, Jawa Timur dengan sampel rumah tangga tani yang hidup atau melakukan kegiatan usaha tani di daerah marginal. Metode analisis yang digunakan untuk menjawab tujuan penelitian adalah persamaan AKE, PPP, dan $\mathrm{KP}$, serta analisis tabel untuk menunjukkan keragaan ketahanan pangan. Hasil dari penelitian ini menunjukkan distribusi rumah tangga tani menurut AKE lebih banyak yang belum tahan pangan $(53 \%)$ tetapi reratanya sudah tahan pangan $(87 \%)$ berarti terdapat disparitas kecukupan energi antar rumah tangga tani. Rumah tangga tani termasuk sudah tahan pangan pada kategori PPP rendah (44\%) dengan distribusi sebesar $87 \%$. Keragaan ketahanan pangan terbesar rumah tangga tani adalah pada kategori kurang pangan dan tahan pangan. Rumah tangga tani daerah marginal di Kabupaten Bojonegoro sudah mandiri pangan untuk kebutuhan makanan pokok berupa beras dengan asumsi panen digunakan untuk mencukupi kebutuhan pangan.

Adapun umur juga menjadi salah satu faktor yang berpengaruh terhadap tingkat ketahanan pangan rumah tangga. Umur memiliki hubungan yang signifikan secara statistik pada tingkat ketahanan pangan. Umur ibu dinilai penting untuk ketahanan pangan rumah tangga karena usia menunjukkan pengalamannya. Ibu yang berusia lebih tua dapat lebih memahami kualitas makanan dan kebutuhan gizi untuk keluarga dibandingkan dengan ibu yang berusia muda (Sharaunga et al., 2016).

Penelitian Utami \& Suprapti, (2020) bertujuan untuk menganalisis (1) modal sosial; (2) Ketahanan pangan; (3) pengaruh modal sosial terhadap ketahanan pangan petani jagung lokal di Desa Guluk-guluk. Penelitian menggunakan 40 responden yang di ambil dengan purposive sampling. Data dikumpulkan dengan penyebaran kuisioner, wawancara dan dokumentasi. Metode analisis data yang digunakan yaitu analisis deskriptif dan analisis regresi linier berganda. Hasil analisis deskriptif menunjukkan bahwa faktor modal sosial yang memiliki nilai paling tinggi adalah adanya jaringan sosial, dan sebagian besar petani jagung lokal berkategori belum tahan pangan. Faktor modal sosial yang mempengaruhi ketahanan pangan adalah kerjasama, partisipasi, kepercayaan dan norma sosial.

Penelitian Praza \& Shamadiyah, (2020) bertujuan untuk mengetahui: (1) mengetahui besarnya proporsi pengeluaran pangan terhadap pengeluaran total rumah tangga petani menurut kelompok pendapatan, (2) mengetahui tingkat konsumsi pangan (energi dan protein) rumah tangga petani Utara berdasarkan strata 
pendapatan dan (3) menganalisis kondisi ketahanan pangan rumah tangga petani menurut kelompok pendapatan. Berdasarkan hasil penelitian di atas dari persamaan pangsa pengeluaran diperoleh persentasi ketahanan pangan rumah tangga petani di Kabupaten Aceh Utara menunjukkan bahwa rumah tangga petani yang tahan pangan sebanyak 25 petani $(41,67 \%)$ dari total sample penelitian. Selanjutnya, diperoleh rumah tangga petani dengan kategori kurang pangan sebanyak 1 petani $(1,67 \%)$, rumah tangga petani dengan kategori rentan pangan sebanyak 2 petani $(3,33 \%)$, dan rumah tangga petani dengan kategori rawan pangan sebanyak 32 petani $(53,33 \%)$ dari total sample penelitian. Hasil penelitian menunjukkan bahwa petani yang memiliki pendapatan rendah berada dalam kategori rawan pangan.

Penelitian Mahendra et al., (2019) bertujuan untuk menganalisis faktor lingkungan terhadap ketahanan pangan karet rumah tangga petani di Kabupaten Kuantan Singingi. Penelitian ini menggunakan metode survei dengan teknik multistage cluster random sampling. Hasil penelitian menunjukkan bahwa makanan Status keamanan petani karet di Kabupaten Kuantan Singingi tidak terjamin. Itu disebabkan oleh pendapatan rumah tangga yang sangat rendah. Analisis statistik menunjukkan bahwa komponen akses transportasi dan akses fasilitas kesehatan secara signifikan pengaruh terhadap ketahanan pangan rumah tangga. Koefisien akses transportasi dan akses ke fasilitas kesehatan masing-masing adalah 127,72 $(p=0,0008)$ dan $114,90(p=0,01)$. Berdasarkan hasil analisis bertahap, akses transportasi dan akses kesehatan fasilitas merupakan parameter yang baik sebagai faktor dominan yang menentukan makanan rumah tangga keamanan petani karet.

Seiring perkembangan teknologi yang sangat pesat, saat ini internet dapat diakses dari manapun baik melalui komputer, laptop maupun telepon seluler de- ngan jenis ponsel pintar (Rahanur \& Hasan, 2020). Menurut data BPS dari hasil pendataan Susenas, pada tahun 2014 persentase penduduk Provinsi NTB usia 5 tahun ke atas yang pernah mengakses internet dalam tiga bulan terakhir sekitar 10,6 persen dan angka ini meningkat menjadi 28.31 persen pada tahun 2018. Peningkatan penggunaan internet ini terjadi baik di daerah perkotaan maupun perdesaan. Tingginya penggunaan internet mencerminkan iklim keterbukaan informasi dan penerimaan masyarakat terhadap perkembangan teknologi dan perubahan menuju masyarakat informasi termasuk juga untuk mengakses informasi yang berkaitan dengan pengetahuan gizi. Leroy et al., (2020) juga pernah melakukan penelitian di Amerika Serikat mengenai tujuan penggunaan teknologi internet. Ditemukan hasil bahwa 65 persen dari mereka yang mengakses internet digunakan untuk memperoleh informasi terkait gizi. Semazzi \& Kakungulu, (2020) juga berpendapat bahwa dengan memasukkan unsur teknologi khususnya akses internet merupakan strategi yang paling efektif untuk memperoleh pengetahuan tentang gizi.

Beberapa penelitian lain menyatakan bahwa ada hubungan korelasi antara ukuran rumah tangga dengan tingkat ketahanan pangan. Ukuran rumah tangga ditemukan memiliki hubungan negatif dengan ketahanan pangan (Akrasi et al., 2020). Rumah tangga dengan ukuran besar memiliki peluang lebih besar untuk menjadi rawan pangan daripada yang berukuran lebih kecil. Semakin besar jumlah orang dewasa yang tidak bekerja dan anak-anak, semakin tinggi pula beban anggota yang bekerja dalam memenuhi biaya pangan rumah tangga. Jika terjadi perubahan jumlah anggota, maka pembuat keputusan dalam rumah tangga akan mengalokasikan ulang ketersediaan resources bagi ukuran rumah tangga yang baru. Namun, beberapa penelitian yang lain juga menemukan bukti bahwa ukuran rumah tang- 
ga tidak signifikan terhadap tingkat ketahanan pangan rumah tangga (Ebeh \& Agama, 2018).

Berkaitan dengan lokasi tempat tinggal, penduduk di daerah perkotaan memiliki derajat ketahanan pangan yang lebih baik dibanding penduduk di daerah pedesaan. Keadaan ini diduga disebabkan oleh relatif sempitnya kesempatan kerja di pedesaan dibanding dengan perkotaan, sehingga rumah tangga pedesaan mempunyai keterbatasan dalam hal sumbersumber pendapatan (Purwaningsih et al., 2015). Namun sebaliknya, Heryanah, (2016) dalam penelitiannya di Jawa Barat menemukan bukti empiris bahwa daerah perkotaan cenderung menunjukkan derajat ketahanan pangan rumah tangga yang lebih rendah (lebih rawan pangan) daripada rumah tangga di daerah perdesaan.

Sebagian besar penelitian menyatakan bahwa pengeluaran rumah tangga memiliki hubungan yang signifikan dan positif terhadap peningkatan ketahanan pangan rumah tangga (Ebeh \& Agama, 2018). Lebih banyak pendapatan (resources) yang tersedia bagi suatu rumah tangga seharusnya dapat ditransfer dalam bentuk pengeluaran untuk makan dan kesehatan. Hal ini akan memberikan implikasi positif terhadap peningkatan asupan gizi rumah tangga.

Ketahanan pangan didefinisikan sebagai suatu kondisi ketersediaan pangan yang cukup bagi setiap orang pada setiap saat dan setiap individu yang mempunyai akses untuk memperolehnya, baik secara fisik maupun ekonomi (Purnasari et al., 2020). Fokus ketahanan pangan tidak hanya pada penyediaan pangan tingkat wilayah tetapi juga ketersediaan dan konsumsi pangan tingkat daerah dan rumah tangga, dan bahkan bagi individu dalam memenuhi kebutuhan gizinya. Untuk mengukur derajat ketahanan rumah tangga, indikator yang digunakan adalah klasifikasi silang antara pangsa pengeluaran pangan dan kecukupan konsumsi energi.
Penelitian ini fokus pada ketahanan pangan rumah tangga. Oleh karena itu, ketahanan pangan wilayah dan daerah tidak akan dibahas disini. Secara umum, tujuan penelitian ini adalah untuk menguji dan menganalisis pengaruh karakteristik ekonomi, demografi dan sosial meliputi tingkat pendidikan ibu, usia ibu, pekerjaan ibu, akses ke internet, ukuran rumah tangga, daerah tempat tinggal, dan pengeluaran rumah tangga terhadap tingkat ketahanan pangan rumah tangga di Provinsi NTB. Penelitian ini berbeda dengan penelitian sebelumnya karena dalam penelitian ini melibatkan bagaimana peran ibu dalam rumah tangga dan juga memasukkan faktor teknologi yaitu variabel akses internet ke dalam model penelitian. Hasil penelitian ini diharapkan dapat menjadi referensi bagi pemerintah, peneliti lainnya, serta bagi masyarakat tentang tingkat ketahanan pangan rumah tangga. Pembahasan selanjutnya pada penelitian ini adalah metode penelitian, hasil dan pembahasan, serta kesimpulan sebagai penutup.

\section{METODE PENELITIAN}

Penelitian ini menggunakan regresi logistik multinomial. Menurut (Dung, 2020), model regresi logistik ada dua bentuk yaitu regresi logistik biner dan multinomial. Regresi logistik biner mensyaratkan variabel terikat terdiri dari dua kategori, sedangkan regresi logistik multinomial mengisyaratkan variabel terikat lebih dari dua kategori. Regresi logistik multinomial merupakan regresi logistik yang digunakan saat variabel dependen mempunyai skala yang bersifat polichotomous atau multinomial (Abdillah et al., 2020). Metode yang digunakan dalam penelitian ini adalah regresi logistik dengan variabel respon berskala nominal dengan tiga kategori.

Regresi logistik multinomial digunakan untuk memeriksa hubungan antara variabel terikat yang berupa data kualitatif dengan variabel bebas yang terdiri dari data kualitatif dan kuantitatif. Regresi logis- 
tik multinomial melibatkan variabel terikat yang mempunyai kategori lebih dari dua dengan variabel bebas kategorik dan atau kontinu (Wang et al., 2020). Suatu variabel terikat $j$ kategori akan membentuk persamaan logit $j-1$ dimana masing-masing persamaan ini membentuk regresi logistik biner yang membandingkan suatu kategori terhadap kategori acuannya. Model penelitian tingkat ketahanan pangan rumah tangga di Provinsi NTB dituliskan sebagai berikut:

$z_{1}=\ln \left(\frac{P(Y=1 \mid x)}{P(Y=0 \mid x)}\right)=\beta_{10}+\beta_{11} E D U C M+$

$\beta_{12} A G E M+\beta_{13} I N F O+\beta_{14}$ WORK +

$\beta_{15} H S I Z E+\beta_{16} R E S+\beta_{17} \ln \_$EXPTOT $+\varepsilon_{1}$

$z_{2}=\ln \left(\frac{P(Y=2 \mid x)}{P(Y=0 \mid x)}\right)=\beta_{20}+\beta_{21} E D U C M+$

$\beta_{22}$ AGEM $+\beta_{23}$ INFO $+\beta_{24}$ WORK +

$\beta_{25} H S I Z E+\beta_{26} R E S+\beta_{27} \ln { }_{-}$EXPTOT $+\varepsilon_{2}$

$z_{3}=\ln \left(\frac{P(Y=3 \mid x)}{P(Y=0 \mid x)}\right)=\beta_{30}+\beta_{31} E D U C M+$

$\beta_{32} A G E M+\beta_{33} I N F O+\beta_{34}$ WORK +

$\beta_{35}$ HSIZE $+\beta_{36}$ RES $+\beta_{37} \ln \_$EXPTOT $+\varepsilon_{3}$

dimana, $z_{1}$ adalah probabilitas rumah tangga memiliki status rentan pangan dibanding rawan pangan, $z_{2}$ adalah probabilitas rumah tangga memiliki status kurang pangan dibanding rawan pangan; dan $z_{3}$ adalah probabilitas rumah tangga memiliki status tahan pangan dibanding rawan pangan. $Y$ merupakan variabel tingkat ketahanan pangan rumah tangga dengan dummy $Y=0$ jika rumah tangga yang memiliki status rawan pangan; $Y=1$ jika rumah tangga yang memiliki status rentan pangan; $Y=2$ jika rumah tangga yang memiliki status kurang pangan; dan $Y=1$ jika rumah tangga yang memiliki status tahan pangan. EDUCM adalah tingkat pendidikan ibu; AGEM adalah umur ibu; INFO merupakan variabel dummy untuk akses ke internet
(INFO =0 jika ibu tidak pernah mengakses internet, INFO =1 jika ibu pernah mengakses internet); WORK adalah variabel dummy untuk status pekerjaan ibu (WORK $=0$ jika ibu tidak bekerja, WORK= 1 jika ibu bekerja); HSIZE adalah ukuran rumah tangga; RES adalah variabel dummy untuk variabel daerah tempat tinggal (RES= 0 jika pedesaan, RES= 1 jika perkotaan); In_EXPTOT adalah logaritma natural pengeluaran total rumah tangga; $\beta_{\text {io }}$ adalah intercept $(i=1,2,3) ; \beta_{\mathrm{ij}}$ adalah koefisien variabel bebas/slope $(i=1,2,3 ; j=1,2, \ldots, 7)$ dan $\varepsilon i$ adalah error term $(i=1,2,3)$.

Analisis regresi logistik multinomial dalam penelitian ini menggunakan bantuan perangkat lunak statistik yaitu Stata versi 13.0. Hasil analisis data tersebut akan disajikan dalam nilai marginal effect. Koefisien dalam model regresi logistik multinomial sulit untuk ditafsirkan atau tidak dapat diartikan secara langsung. Oleh karena itu, perlu menghitung nilai marginal effect untuk memberikan pemahaman yang lebih baik tentang model regresi logistik multinomial. Nilai marginal effect mampu mengukur pengaruh perubahan satu unit variabel bebas terhadap probabilitas kategori ke-i.

Data yang digunakan dalam penelitian ini merupakan data mikro level individu yang bersumber dari Survei Sosial Ekonomi Nasional (SUSENAS) modul KOR dan modul Konsumsi Pengeluaran (KP) Maret 2018 berupa data cross sectional oleh Badan Pusat Statistik (BPS) Provinsi NTB. Jumlah observasi pada penelitian ini sebanyak 5.490 rumah tangga dari 6.320 rumah tangga yang tersedia, karena penelitian ini hanya meneliti rumah tangga dengan anggota rumah tangga wanita usia produktif (15 - 64 tahun) berstatus pernah menikah.

Klasifikasi tingkat ketahanan pangan menurut Jonsson dan Toole (1991) adalah sebagai berikut: (1) rumah tangga dikategorikan tahan pangan apabila memiliki pangsa pengeluaran pangan rendah 
yaitu kurang dari $60 \%$ dari pengeluaran rumah tangga dan cukup mengkonsumsi energi yaitu lebih dari $80 \%$ Angka Kecukupan Energi (AKE); (2) rumah tangga kurang pangan apabila memiliki pangsa pengeluaran pangan rendah dan konsumsi energi kurang ( $\leq 80 \%$ dari AKE); (3) rumah tangga rentan pangan yaitu rumah tangga yang memiliki pangsa pengeluaran pangan tinggi yaitu lebih atau sama dengan $60 \%$ dari pengeluaran rumah tangga namun cukup mengkonsumsi energi; dan (4) rumah tangga termasuk kategori rawan pangan apabila memiliki pangsa pengeluaran pangan tinggi dan tingkat konsumsi energinya kurang. asupan energi, dihitung sebagai berikut

$T K E_{i}=\frac{N_{i}}{S t d_{i}} \times 100 \%$

dengan $\mathrm{N}_{\mathrm{i}}$, total asupan gizi rumah tangga merupakan total asupan aktual rumah tangga ke-i dalam seminggu dan Std merupakan total asupan standar gizi rumah tangga ke-i yang telah memperhitungkan kebutuhan minimal asupan gizi menurut umur dan jenis kelamin anggota rumah tangga. Acuan standar angka kecukupan energi (AKE) merujuk pada Angka Kecukupan Gizi (AKG) Nasional berdasarkan Peraturan Kementerian Kesehatan No.75 tahun 2013.

Tabel 1.

Derajat Ketahanan Pangan Rumah tangga

\begin{tabular}{lcc}
\hline \multicolumn{1}{c}{$\begin{array}{c}\text { Tingkat Konsumsi } \\
\text { Energi }\end{array}$} & \multicolumn{2}{c}{ Pangsa Pengeluaran Pangan } \\
\cline { 2 - 3 } & \multicolumn{1}{c}{$\begin{array}{c}\text { Rendah } \\
(<60 \% \text { pengeluaran total })\end{array}$} & $\begin{array}{c}\text { Tinggi } \\
(\geq 60 \% \text { pengeluaran total })\end{array}$ \\
\hline $\begin{array}{l}\text { Cukup } \\
(>80 \% \text { AKE })\end{array}$ & Tahan Pangan & Rentan Pangan \\
\hline $\begin{array}{l}\text { Kurang } \\
(\leq 80 \% \text { AKE })\end{array}$ & Kurang Pangan & Rawan Pangan \\
\hline Sumber : Diadopsi dari Jonsson dan Toole (1991) dalam Maxwell dkk. (2000)
\end{tabular}

Pangsa pengeluaran pangan (PPP) merupakan rasio antara pengeluaran pangan terhadap total pengeluaran rumah tangga, dirumuskan sebagai berikut:

$P P P_{i}=\frac{P P_{i}}{T P_{i}} \times 100 \%$

dimana, $\mathrm{PP}_{\mathrm{i}}$ adalah pengeluaran pangan rumah tangga ke-i, dan $\mathrm{TP}_{\mathrm{i}}$ adalah total pengeluaran rumah tangga ke-i. Total pengeluaran rumah tangga merupakan hasil perhitungan gabungan dari pengeluaran untuk makanan selama seminggu dan pengeluaran untuk kelompok nonmakanan selama sebulan.

Konsumsi energi adalah jumlah kalori dari pangan yang dikonsumsi oleh rumah tangga. Tingkat konsumsi energi (TKE) dihitung dengan membandingkan kondisi asupan energi aktual dan standar

\section{HASIL DAN PEMBAHASAN}

Alokasi kebutuhan rumah tangga dapat dilihat berdasarkan pengeluaran rumah tangga yang terdiri dari pengeluaran makanan dan bukan makanan. Proporsi pengeluaran makanan terhadap total pengeluaran atau pangsa pengeluaran pangan merupakan indikator dini yang mampu menggambarkan derajat ketahanan pangan di tingkat rumah tangga. Gambar 1 menunjukkan pangsa pengeluaran rumah tangga di Provinsi NTB yaitu sebesar $56,13 \%$ untuk pengeluaran pangan dan 43,87\% untuk pengeluaran non pangan. Pangsa pengeluaran pangan berhubungan negatif dengan ketahanan pangan. Semakin tinggi pangsa pengeluaran pangan maka akan mengurangi ketahanan pangan. 


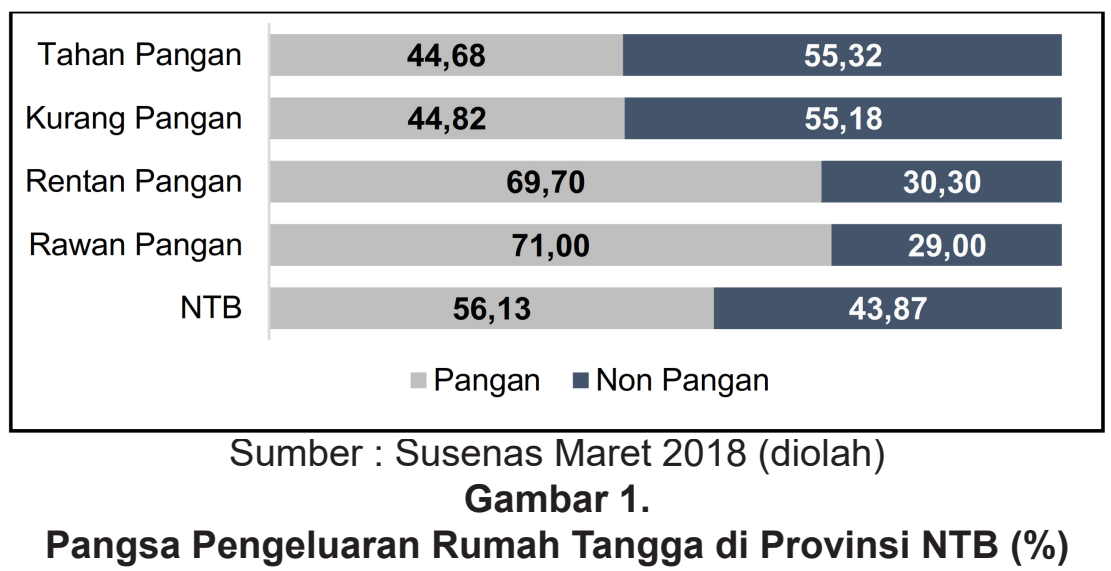

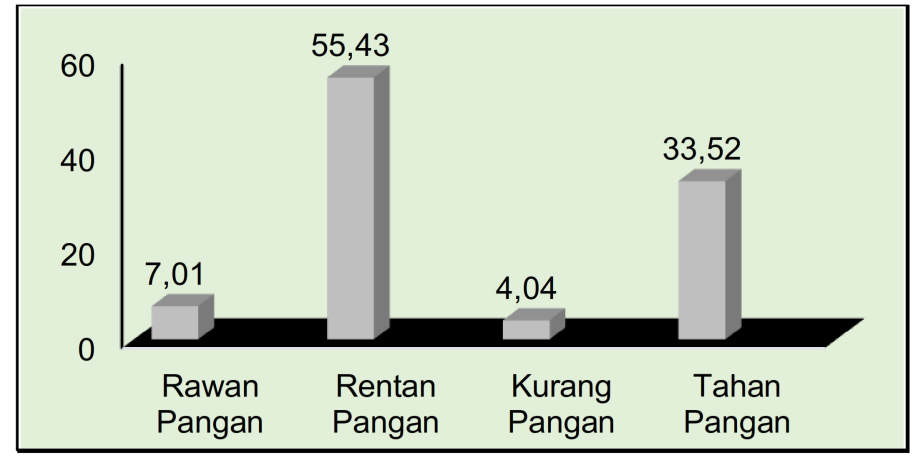

Sumber : Susenas Maret 2018 (diolah)

Gambar 2.

\section{Distribusi Ketahanan Pangan Rumah Tangga di Provinsi NTB (\%)}

Distribusi rumah tangga di Provinsi NTB menurut tingkat ketahanan pangan dengan metode Jonsson dan Toole adalah $7,01 \%$ rawan pangan, $55,43 \%$ rentan pangan, 4,04\% kurang pangan dan 33,52\% tahan pangan. Berdasarkan indikator yang digunakan, rumah tangga rentan pangan memiliki proporsi paling banyak. Kelompok rumah tangga ini memiliki tingkat kecukupan energi yang cukup (>80\%), namun memiliki pangsa pengeluaran pangan yang tinggi $(>60 \%)$ dari total pengeluaran rumah tangga. Kelompok rumah tangga ini secara ekonomi memiliki kemampuan ekonomi yang kurang, karena proporsi pengeluaran rumah tangga lebih besar di- belanjakan untuk pangan daripada untuk kebutuhan non pangan.

Gambaran umum keadaan rumah tangga dalam observasi disajikan dalam tabel 2. Rata-rata tingkat pendidikan ibu pada penelitian ini adalah 7,17 atau setara dengan Sekolah Menengah Pertama (SMP) tingkat pertama. Sedangkan ratarata umur ibu yang diteliti adalah 42 tahun. Untuk persentase rata-rata ibu yang pernah mengakses internet dalam 3 bulan terakhir adalah sebesar $18 \%$. Selain itu, persentase rata-rata ibu yang bekerja adalah sebesar $62 \%$. Terdapat $42 \%$ ratarata rumah tangga yang diteliti tinggal di perkotaan. Rata-rata pengeluaran total 
Tabel 2.

Deskriptif Statistik Variabel

\begin{tabular}{|c|c|c|c|c|}
\hline Variabel & Rata-rata & St Dev & Min & Max \\
\hline $\begin{array}{l}\text { Tingkat Pendidikan Ibu } \\
\text { (EDUCM) }\end{array}$ & 7,17 & 4,73 & 0 & 18 \\
\hline Ùmur Ibu (AGEM) & 41,43 & 11,31 & 15 & 64 \\
\hline Akses Ibu ke Internet (INFO) & 0,18 & 0,39 & 0 & 1 \\
\hline Status Pekerjaan (WORK) & 0,62 & 0,49 & 0 & 1 \\
\hline Ukuran Rumah Tangga (HSIZE) & 3,74 & 1,39 & 1 & 11 \\
\hline Daerah Tempat Tinggal (RES) & 0,42 & 0,49 & 0 & 1 \\
\hline $\begin{array}{l}\text { Total Pengeluaran Rumah } \\
\text { Tangga (EXPTOT) }\end{array}$ & 3.616 .629 & 3.322 .540 & 279.929 & 71.627 .548 \\
\hline
\end{tabular}

Sumber : Susenas Maret 2018 (diolah)

Tabel 3

Hasil Regresi Logistik Multinomial

\begin{tabular}{|c|c|c|c|}
\hline \multirow{2}{*}{ Variabel } & \multicolumn{3}{|c|}{$\begin{array}{c}\text { Marginal Effect } \\
\text { (Rawan Pangan = Kategori Acuan) }\end{array}$} \\
\hline & $\begin{array}{c}\text { Model } 1 \\
\text { (Rentan Pangan) }\end{array}$ & $\begin{array}{c}\text { Model } 2 \\
\text { (Kurang Pangan) }\end{array}$ & $\begin{array}{c}\text { Model } 3 \\
\text { (Tahan Pangan) }\end{array}$ \\
\hline EDUCM (tahun) & $\begin{array}{r}-0,01824^{\star \star \star} \\
(0,00201) \\
\end{array}$ & $\begin{array}{r}0,00457^{* * *} \\
(0,0008) \\
\end{array}$ & $\begin{array}{r}0,01305^{\star \star \star} \\
(0,00195) \\
\end{array}$ \\
\hline AGEM (tahun) & $\begin{array}{r}-0,00551^{* * *} \\
(0,00076) \\
\end{array}$ & $\begin{array}{r}0,00118^{* * *} \\
(0,00031) \\
\end{array}$ & $\begin{array}{r}0,00446^{* * *} \\
(0,00074) \\
\end{array}$ \\
\hline $\begin{array}{l}\text { INFO } \\
\text { (Ibu punya akses ke } \\
\text { internet, dummy }=1 \text { ) }\end{array}$ & $\begin{array}{r}-0.07634^{* * *} \\
(0,02342)\end{array}$ & $\begin{array}{c}0.01949^{*} \\
(0,01091)\end{array}$ & $\begin{array}{l}0.05808^{* *} \\
(0,02255)\end{array}$ \\
\hline $\begin{array}{l}\text { WORK } \\
\text { (Bekerja, dummy =1) }\end{array}$ & $\begin{array}{r}0,00059 \\
(0,01521) \\
\end{array}$ & $\begin{array}{r}-0,00388 \\
(0,00641)\end{array}$ & $\begin{array}{r}0,00609 \\
(0,01482) \\
\end{array}$ \\
\hline HSIZE (orang) & $\begin{array}{r}0,11639^{* * *} \\
(0,00663)\end{array}$ & $\begin{array}{r}0,01153^{* * *} \\
(0,00235) \\
\end{array}$ & $\begin{array}{r}-0,14426^{* * *} \\
(0,00652) \\
\end{array}$ \\
\hline $\begin{array}{l}\text { RES } \\
\text { (Perkotaan, dummy }=1)\end{array}$ & $\begin{array}{r}-0,00139 \\
(0,01533)\end{array}$ & $\begin{array}{r}0,01167^{*} \\
(0,00651) \\
\end{array}$ & $\begin{array}{r}-0,01002 \\
(0,01494) \\
\end{array}$ \\
\hline LN_EXPTOT (persen) & $\begin{array}{r}-0,0003^{* * *} \\
(0,00002) \\
\end{array}$ & $\begin{array}{r}-0,00003^{* * *} \\
(0,0001) \\
\end{array}$ & $\begin{array}{r}0,00043^{* * *} \\
(0,00001) \\
\end{array}$ \\
\hline \multicolumn{4}{|l|}{ Goodness of Fit } \\
\hline Count $R^{2}$ & & 0,557 & \\
\hline Prob > chi ${ }^{2}$ & & 0,000 & \\
\hline Jumlah Observasi & & 5490 & \\
\hline
\end{tabular}

Nilai dalam kurung menunjukkan nilai standard error

Rumah tangga pada penelitian ini adalah sebesar Rp 3.616.629 per bulan. Pengeluaran terendah sebesar Rp 279.929 per bulan dan pengeluaran tertinggi mencapai Rp 71.627.548 per bulan. Salahsatu faktor yang menyebabkan tinggi rendahnya pengeluaran rumah tangga adalah banyaknya jumlah tanggungan (ukuran rumah tangga). Pada penelitian ini, jumlah tanggungan terendah sebanyak 1 orang dan tertinggi mencapai 11 orang per rumah tangga.

Hasil empiris model regresi logistik multinomial disajikan berdasarkan tabel 3. Hasil regresi logistik multinomial tingkat ketahanan pangan rumah tangga di Provinsi NTB menunjukkan nilai count Rsquared sebesar 0,557. Dapat dikatakan 
bahwa dalam model tersebut, karakteristik ekonomi, demografi dan sosial meliputi tingkat pendidikan ibu, usia ibu, pekerjaan ibu, akses ke internet, ukuran rumah tangga, daerah tempat tinggal, dan pengeluaran rumah tangga sebagai variabel bebas mampu menjelaskan variabel terikat yaitu tingkat ketahanan pangan rumah tangga di Provinsi NTB sebesar 55,7 persen, sedangkan yang lain dipengaruhi oleh variabel lain di luar model.

Model pertama menunjukkan variabel tingkat pendidikan ibu, umur ibu, akses ke internet, ukuran rumah tangga dan total pengeluaran rumah tangga berpengaruh signifikan terhadap probabilitas rumah tangga memiliki status rentan pangan. Variabel ukuran rumah tangga berpengaruh positif terhadap probabilitas rumah tangga memiliki status rentan pangan. Sementara itu, tingkat pendidikan ibu, umur ibu, akses ke internet, dan total pengeluaran rumah tangga memiliki pengaruh negatif pada probabilitas rumah tangga memiliki status rentan pangan. Model kedua menunjukkan bahwa semua variabel bebas berpengaruh signifikan terhadap probabilitas rumah tangga memiliki status kurang pangan kecuali variabel status pekerjaan. Variabel tingkat pendidikan ibu, umur ibu, akses ke internet, ukuran rumah tangga dan daerah tempat tinggal memiliki pengaruh positif pada probabilitas rumah tangga memiliki status kurang pangan. Model ketiga menunjukkan variabel tingkat pendidikan ibu, umur ibu, dan akses ke internet berpengaruh signifikan dan positif terhadap probabilitas rumah tangga memiliki status tahan pangan. Sementara itu, variabel status pekerjaan dan daerah tempat tinggal tidak berpengaruh signifikan terhadap probabilitas rumah tangga memiliki status tahan pangan dibanding rawan pangan.

Dengan menggunakan asumsi bahwa variabel lain dalam model dianggap konstan sehingga setiap variabel pada tabel 3 dapat ditafsirkan. Model pertama menunjukkan bahwa untuk setiap kenai- kan tingkat pendidikan ibu sebesar satu tahun, probabilitas rumah tangga memiliki status rentan pangan akan menurun sebesar 0.01824 atau 1,8 persen. Begitu juga pada variabel umur ibu, setiap umur bertambah satu tahun akan menurunkan probabilitas rumah tangga memiliki status rentan pangan sebesar 0,00551 atau 0,6 persen. Variabel lainnya yaitu akses ke internet, dan total pengeluaran rumah tangga; untuk setiap kenaikan satu persen masing-masing variabel tersebut akan menurunkan probabilitas rumah tangga memiliki status rentan pangan sebesar 0,07634 atau 7,6 persen dan 0,0003 atau 0,03 persen dibanding rawan pangan. Sementara itu untuk variabel ukuran rumah tangga, setiap ada kenaikan ukuran rumah tangga sebanyak satu orang akan menaikan probabilitas rumah tangga memiliki status rentan pangan sebesar 0,11639 atau 11,6 persen.

Model kedua menunjukkan bahwa semua variabel bebas kecuali variabel status pekerjaan dan pengeluaran rumah tangga; memiliki hubungan positif terhadap probabilitas rumah tangga memiliki status kurang pangan. Hal ini dapat diartikan bahwa hampir seluruh variabel bebas mempengaruhi probabilitas rumah tangga memiliki status kurang pangan dibanding status rawan pangan. Pada model kedua, variabel tingkat pendidikan ibu akan meningkatkan probabilitas rumah tangga sebesar 0,00457 atau 0,5 persen untuk memiliki status kurang pangan. Variabel umur juga akan meningkat probabilitasnya untuk rumah tangga memiliki status kurang pangan sebesar $0,00118(0,1$ persen). Begitu juga yang terjadi pada rumah tangga yang tinggal diwilayah perkotaan, akan meningkat probabilitasnya sebesar 0,01167 (1,1 persen) untuk memiliki status kurang pangan dibanding rawan pangan. Sementara itu untuk variabel ukuran rumah tangga, setiap ada kenaikan jumlah anggota rumah tangga sebanyak satu orang maka akan menaikan probabilitas 
rumah tangga memiliki status kurang pangan sebesar 0,01153 atau 1,1 persen.

Model ketiga dalam penelitian ini menunjukkan bahwa untuk setiap kenaikan satu tahun pendidikan ibu, probabilitas rumah tangga untuk 'memiliki status tahan pangan akan naik sebesar 0.01305 (1,3 persen). Begitu juga pada variabel umur ibu, ketika umur bertambah satu tahun maka akan menaikan probabilitas rumah tangga memiliki status tahan pangan sebesar 0,00446 (0,5 persen). Ibu yang memiliki akses terhadap internet akan meningkat probabilitas nya untuk memiliki rumah tangga yang tahan pangan sebesar 0,05808 (5,8 persen). Demikian juga dengan variabel pengeluaran rumah tangga, setiap ada kenaikan satu persen pengeluaran rumah tangga, probabilitas rumah tangga untuk 'tahan pangan akan naik sebesar 0,00043 (0,04 persen). Sementara itu, ukuran rumah tangga akan menurunkan probabilitas rumah tangga memiliki status tahan pangan sebesar 0,14426 (14,4 persen).

Tingkat pendidikan ibu menunjukkan hubungan yang signifikan terhadap probablilitas status ketahanan pangan rumah tangga. Hal tersebut berarti bahwa tingkat pendidikan ibu berkontribusi pada penentuan status ketahanan pangan rumah tangga. Hal ini sejalan dengan penelitian yang dilakukan oleh Kaiser et al. (2003) yang menemukan bahwa tingkat pendidikan ibu berkorelasi positif dengan ketahanan pangan rumah tangga di California. Tingkat pendidikan yang lebih tinggi dari ibu membantu mengurangi peluang rumah tangga menjadi rawan pangan karena dalam rumah tangga tersebut diasumsikan memiliki teknik manajemen keuangan dan pengetahuan gizi yang lebih baik untuk memastikan pasokan makanan yang merata dan menyeluruh sesuai kebutuhan gizi masing-masing anggota rumah tangga. Hal ini menunjukkan pentingnya investasi modal manusia dalam meningkatkan status ketahanan pangan rumah tangga (Manesa et al., 2008).

Berkaitan dengan umur, variabel umur memiliki hubungan yang negatif dengan tingkat ketahanan pangan rumah tangga pada model pertama, namun berkorelasi positif pada model kedua dan ketiga. Namun secara umum, umur ibu memiliki hubungan yang signifikan secara statistik pada tingkat ketahanan pangan. Hasil penelitiannya menunjukkan bahwa usia ibu memiliki pengaruh positif dan signifikan terhadap tingkat ketahanan pangan rumah tangga di Amerika Serikat. Karena dengan bertambahnya usia, ibu cenderung memiliki wawasan yang lebih baik mengenai penyediaan makanan yang bergizi dan dibutuhkan untuk keluarga, serta dapat mengalokasikan pengeluaran rumah tangganya untuk pos-pos pengeluaran yang lain seperti pendidikan dan kesehatan.

Variabel berikutnya adalah akses ke internet. Berdasarkan hasil olah data ada 18,45 persen rumah tangga pernah mengakses internet dan 58,34 persen dari rumah tangga yang pernah mengakses internet memiliki status tahan pangan. Hasil regresi logistik juga menunjukkan bahwa akses ke internet memiliki hubungan yang signifikan secara statistik terhadap tingkat ketahanan pangan rumah tangga. Akses internet merupakan strategi yang paling efektif untuk memperoleh pengetahuan tentang gizi. Temuan ini memberikan sinyal positif bagi pemerintah dalam upaya peningkatan ketahanan pangan rumah tangga, karena BPS dalam publikasinya juga menyatakan bahwa jumlah pengguna internet terus mengalami peningkatan dari tahun ke tahun (Damayanti \& Khoirudin, 2016).

Ukuran rumah tangga berkaitan dengan besarnya tanggungan yang harus ditanggung oleh anggota produktif dalam rumah tangga. Pada model pertama dan kedua, variabel ukuran rumah tangga berkorelasi positif terhadap probabilitas rumah tangga memiliki status rentan pangan dan kurang pangan dibanding rawan pangan. 
Namun, berbeda dengan model ketiga. Pada model ketiga, variabel ukuran rumah tangga berkorelasi negatif terhadap probabilitas rumah tangga memiliki status tahan pangan dibanding rawan pangan. Ukuran rumah tangga ditemukan memiliki hubungan negatif dengan ketahanan pangan. Rumah tangga dengan ukuran besar memiliki peluang lebih besar untuk menjadi rawan pangan daripada yang berukuran lebih kecil. Semakin besar jumlah orang dewasa yang tidak bekerja dan anak-anak, semakin tinggi pula beban anggota yang bekerja dalam memenuhi biaya pangan rumah tangga.

Pengeluaran rumah tangga memiliki hubungan yang positif dan signifikan terhadap probabilitas rumah tangga memiliki status tahan pangan. Hasil yang sama yang menyatakan bahwa pengeluaran rumah tangga memiliki hubungan yang signifikan dan positif terhadap peningkatan ketahanan pangan rumah tangga. Besarnya pengeluaran rumah tangga biasanya dipengaruhi oleh seberapa besar pendapatan rumah tangga. Peningkatan pendapatan akan mempengaruhi besarnya daya beli rumah tangga, sehingga akses ekonomi terhadap pemenuhan pangan akan menjadi lebih mudah. Hal senada dinyatakan oleh Purwaningsih et al., (2015). Menurut Purwaningsih et al., (2015) besarnya pendapatan rumah tangga akan memberikan kemampuan daya beli untuk membeli sesuatu dengan lebih baik termasuk membeli pangan dengan kualitas yang lebih baik.

\section{PENUTUP}

Distribusi rumah tangga di Provinsi NTB menurut tingkat ketahanan pangan dengan metode Jonsson dan Toole adalah $7,01 \%$ rawan pangan, $55,43 \%$ rentan pangan, 4,04\% kurang pangan dan 33,52\% tahan pangan. Berdasarkan hasil analisis regresi logistik multinomial karakteristik ekonomi, demografi dan sosial yang meliputi tingkat pendidikan ibu, umur ibu, akses ibu ke internet, ukuran rumah tangga dan pengeluaran rumah tangga ditemukan berpengaruh signifikan terhadap tingkat ketahanan pangan rumah tangga di provinsi NTB.

Variabel daerah tempat tinggal ditemukan tidak berpengaruh terhadap tingkat ketahanan pangan rumah tangga. Hal ini menunjukkan bahwa tingkat ketahanan pangan rumah tangga tidak dipengaruhi oleh keberadaan rumah tangga tinggal di pedesaan ataupun perkotaan. Demikian juga dengan status pekerjaan ibu. Ibu yang bekerja atau tidak bekerja, tidak berpengaruh terhadap tingkat ketahanan pangan rumah tangga. Hasil lainnya menunjukkan bahwa tingkat pendidikan ibu memiliki peran penting dalam menentukan tingkat pangan rumah tangga. Hal ini menunjukkan pentingnya investasi modal manusia dalam meningkatkan status ketahanan pangan rumah tangga.

Tingkat ketahanan pangan rumah tangga dalam penelitian ini hanya dianalisis berdasarkan variabel tingkat pendidikan ibu, umur ibu, peluang ibu akses ke internet, ukuran rumah tangga, daerah tempat tinggal dan pengeluaran rumah tangga. Untuk penelitian selanjutnya, perlu ditambahkan beberapa variabel seperti akses terhadap fasilitas kesehatan, akses ke pasar, harga komoditas makanan dan variabel lainnya yang dapat berpengaruh terhadap ketahanan pangan rumah tangga. Keterbatasan berikutnya adalah penggunaan data cross section, sehingga penelitian ini hanya bisa menjelaskan fenomena yang terjadi terkait dengan ketahanan pangan rumah tangga pada satu titik waktu saja yaitu tahun 2018. Untuk penelitian selanjutnya, disarankan menggunakan data time-series untuk melihat pola perkembangan ketahanan pangan rumah tangga dari waktu ke waktu, sehingga tren tingkat ketahanan pangan dapat dianalisis lebih mendalam.

\section{DAFTAR PUSTAKA}


Abdillah, A., Sutisna, A., Tarjiah, I., Fitria, D., \& Widiyarto, T. (2020). Application of Multinomial Logistic Regression to analyze learning difficulties in statistics courses. Journal of Physics: Conference Series, 1490, 1-6. https://doi. org/10.1088/1742-6596/1490/1/012012

Akrasi, R. O., Eddico, P. N., \& Adarkwah, R. (2020). Income Diversification Strategies and Household Food Security among Rice Farmers: Pointers to Note in the North Tongu District of Ghana. Journal of Food Security, 8(3), 77-88.

Damayanti, V. L., \& Khoirudin, R. (2016). Analisis Faktor - Faktor Yang Mempengaruhi Ketahanan Pangan Rumah Tangga Petani (studi Kasus: Desa Timbulharjo, Sewon, Bantul). Jurnal Ekonomi \& Studi Pembangunan, 17(2), 89-96. https://doi.org/10.18196/ jesp.17.2.3735

Dung, L. T. (2020). A Multinomial Logit Model Analysis of Farmers' Participation in. Applied Economics Journal, 27(1), $1-22$.

Ebeh, J. E., \& Agama, S. A. (2018). Determinants of Food Security Among Households in Dekina Local Government Area of Kogi State, Nigeria. Lafia Journal of Economics and Management Sciences, 3(2), 18.

Heryanah, H. (2016). Ketahanan Pangan Rumah Tangga Di Jawa Barat: Analisis Data Susenas 2012. Populasi, 24(2), 80-90. https://doi.org/10.22146/ jp. 27231

Kara, A. M., \& Kithu, L. M. (2020). Education Attainment of Head of Household and Household Food Security: A Case for Yatta Sub-County, Kenya. American Journal of Educational Research, 8(8), 558-566.

Leroy, J. L., K Olney, D., Bliznashka, L., \& Ruel, M. (2020). Tubaramure, a Food-
Assisted Maternal and Child Health and Nutrition Program in Burundi, Increased Household Food Security and Energy and Micronutrient Consumption, and Maternal and Child Dietary Diversity: A Cluster-Randomized Controlled Trial. The Journal of Nutrition, 150(4), 945957. https://doi.org/10.1093/jn/nxz295

Mahendra, I., Rasyad, A., \& Nurhidayah, T. (2019). Dampak Faktor Lingkungan Terhadap Ketahanan Pangan Rumah Tangga Petani Karet Di Kabupaten Kuantan Singingi. Jurnal IImu Lingkungan, 13(1), 1-14.

Manesa, J., Baliwati, Y. F., \& Tanziha, I. (2008). Ketahanan Pangan Rumah Tangga Di Desa Panghasil Damar Kabupaten Lampung Barat. Jurnal Gizi dan Pangan, 3(3), 172-179. https:// doi.org/10.25182/jgp.2008.3.3.172-179

Mulyo, J. H., Sugiyarto, S., \& Widada, A. W. (2016). Ketahanan Dan Kemandirian Pangan Rumah Tangga Tani Daerah Marginal Di Kabupaten Bojonegoro. Agro Ekonomi, 26(2), 121-128. https:// doi.org/10.22146/agroekonomi.17265

Noviani, N. E., Kandarina, B. I., \& Nisa, F. Z. (2020). Houesehold food security is a risk factor of type 2 diabetic mellitus. Jurnal Gizi Dan Dietetik Indonesia (Indonesian Journal of Nutrition and Dietetics), 8(1), 22-29. https://doi. org/10.21927/ijnd.2020.8(1).22-29

Praza, R., \& Shamadiyah, N. (2020). Analisis Hubungan Pengeluaran Dengan Ketahanan Pangan Rumah Tangga Petani Di Kabupaten Aceh Utara. Jurnal AGRIFO, 5(1), 23-33.

Purnasari, N., Juwitangtyas, T., \& Sabarisman, I. (2020). Household food security during Covid-19 pandemic in Daerah Istimewa Yogyakarta, Indonesia. Sustinere: Journal of Environment and Sustainability, 4(2), 132-143. https:// doi.org/10.22515/sustinere.jes.v4i2.118 
Purwaningsih, Y., Hartono, S., Masyhuri, M., \& Mulyo, J. H. (2015). Pola Pengeluaran Pangan Rumah Tangga Menurut Tingkat Ketahanan Pangan Di Provinsi Jawa Tengah. Jurnal Ekonomi Pembangunan: Kajian Masalah Ekonomi dan Pembangunan, 11(2), 236-253. https://doi.org/10.23917/jep.v11i2.327

Rahanur, M., \& Hasan, S. A. (2020). Assessment of Food Security Status and the Determinants of Food Security in Selected Households from Coastal Area of Noakhali, Bangladesh. Indian Journal of Public Health Research \& Development, 11(9), 210-217.

Semazzi, J. B., \& Kakungulu, M. (2020). Household determinants of food security in rural Central Uganda. African Journal of Agricultural Research, 16(9), 8.

Sharaunga, S., Mudhara, M., \& Bogale, A. (2016). Effects of 'women empowerment' on household food security in rural KwaZulu-Natal province. Development Policy Review, 34(2), 223-252. https://doi.org/10.1111/dpr.12151

Utami, Q., \& Suprapti, I. (2020). Faktor Modal Sosial Terhadap Ketahanan Pangan Rumah Tangga Petani Jagung Lokal Desa Guluk Guluk Kabupaten Sumenep. AGRISCIENCE, 1(1), 138-150.

Wang, X., Zhao, X., \& Liu, B. (2020). Design and pricing of extended warranty menus based on the multinomial logit choice model. European Journal of Operational Research, 287(1), 237-250. https://doi. org/10.1016/j.ejor.2020.05.012 